\title{
Effect of Bacillus subtilis on Aeromonas hydrophila infection resistance in juvenile freshwater prawn, Macrobrachium rosenbergii (de Man)
}

\author{
Mehran Avakh Keysami • Masoumeh Mohammadpour
}

Received: 15 December 2011/Accepted: 20 August 2012/Published online: 2 September 2012

(C) Springer Science+Business Media B.V. 2012

\begin{abstract}
This experiment was carried out to investigate the potential probiotics properties of Bacillus subtilis in protecting of juvenile freshwater prawn, Macrobrachium rosenbergii against Aeromonas hydrophila infection. A B. subtilis bacterium isolated from gut of juvenile prawns was added to the prawns feed at $10^{8}$ cells $\mathrm{g}^{-1}$ feed. There were significant differences $(P<0.05)$ between $B$. subtilis-treated and control groups in growth and survival enhancement of juvenile prawns after 60 days of feeding trial. Sixty days after $B$. subtilis feeding trial, the prawns were challenged by bath exposure to A. hydrophila $\left(10^{7}\right.$ cells $\left.\mathrm{mL}^{-1}\right)$ for 28 days. Four weeks after challenge, there was significant difference in the survival of prawns between $B$. subtilis-treated groups $(88.33 \%)$ and control groups $(20.81 \% ; P<0.05)$. In addition, the control groups had an unhealthy external appearance, while the treated groups, appeared healthy and normal. From this, it was concluded that the selected $B$. subtilis may be a promising probiotics for protection of prawns from A. hydrophila infection.
\end{abstract}

Keywords M. rosenbergii $\cdot$ Probiotics $\cdot$ Challenge test $\cdot$ A. hydrophila $\cdot$ B. subtilis

\section{Introduction}

The giant freshwater prawn, $M$. rosenbergii (de Man), has commanded significant attention in tropical freshwater aquaculture research and development. The characteristics that make the culture of this species attractive include breeding easily in captivity, high hatching rate, high quality meat and in many countries, high market value. However, the relatively low survival of larval and juvenile stages often prevents the development of full economic

M. A. Keysami ( $\square)$

Department of Aquaculture, Persian Gulf Jihad Agriculture Technical and Vocational Higher Education Center, 3588 Bushehr, Iran

e-mail: dr.keysami@gmail.com

M. Mohammadpour

Research Management Center, Bushehr University of Medical Sciences, Bushehr, Iran e-mail: mohammadpour@bpums.ac.ir 
potential of this crustacean (New et al. 2010). The majority of the freshwater prawn mortality can be attributed to the involvement of pathogenic bacteria (Hoa et al. 2000; Scan 2003; Keysami et al. 2007). The Aeromonas spp., Enterococcus spp. and Vibrio spp. are among the most important bacterial pathogens of cultured prawns responsible for a number of diseases (Keysami et al. 2007). Probiotics have been considered a possible solution to reduce these diseases problems. During the recent years, several trials were conducted with micro-organisms known to be probiotics to improve the culture of food species and to improve human health and welfare (Rengpipat et al. 1998; Verschuere et al. 2000). Probiotics are live micro-organisms that when consumed in adequate amount confer a health benefit for the host (FAO/WHO 2001). Appropriate probiotics applications were shown to improve intestinal microbial balance, thus leading to improved feed utilization (FAO 2007; Keysami et al. 2012) and reduced pathogenic problems in the gastrointestinal tract (Scan 2003). In the aquaculture industry, several probiotics species have been used, including Lactobacillus sp. (Abraham et al. 2007), Saccharomyces sp. (Rumsey et al. 2007), Bacillus sp. (Balcazar et al. 2004; Meunpol et al. 2003; Keysami et al. 2007) and mixed cultures (Sotomayure and Balcazar 2003; Meunpol et al. 2003; Salinas et al. 2005; Aly et al. 2008). The trials demonstrated the growth promotion of fish and crustaceans compared to control groups. Those results were most promising and gave confidence that further improvements in probiotics applications were possible (Irianto and Austin 2002). Austin et al. (1995) found that the probiont Vibrio alginolyticus applied to salmon (Salmo salar) could reduce diseases caused by A. salmonicida, V. anguillarum and V. ordalii. However, probiotics application in aquaculture was extensive, especially for freshwater prawn culture (Venkat et al. 2004).

It is apparent that the majority of probiotics for nutritional effect comprise lactic acid bacteria, notably Lactobacillus sp., Bifidobacterium sp. and Streptococcus sp. (Irianto and Austin 2002), because lactic acid bacteria formed a common and important component of the normal micro-biota in the gastrointestinal tracts of healthy fish and mammals (Ringo and Gatesoupe 1998; Abraham et al. 2008). There are no reports of lactic acid bacteria in M. rosenbergii as a common component of micro-biota (Cai et al. 1999; Venkat et al. 2004; Keysami et al. 2005), but Bacillus sp. is known to form a major component of the normal micro-biota in the M. rosenbergii gastrointestinal tracts (Colorni 1985; Anderson et al. 1989; Keysami et al. 2005). Therefore, the objective of this research was to evaluate the effect of B. subtilis on A. hydrophila infection resistance in juvenile freshwater prawn, $M$. rosenbergii (de Man).

\section{Materials and methods}

Preparation of experimental prawns and design

A feeding trial experiment and a challenge test were conducted from 25 June to 25 September in 2010. A total of 240 juvenile prawns (M. rosenbergii) with no external signs of infection and no behavioral abnormalities were obtained from a hatchery at Ahvaz, Iran. The forty juvenile prawns of size ranging from 0.39 to $0.46 \mathrm{~g}$ were introduced into each of 6 glass aquaria of $60 \mathrm{~L}$ capacity $\left(60 \times 30 \times 30 \mathrm{~cm}^{3}\right)$. The mean weights of prawns in 6 aquaria were not significantly different $(P>0.05)$. The aquaria were filled with $360 \mathrm{~L}$ tap water with characteristics included $\mathrm{pH}=7.17$; electrical conductivity $(\mathrm{Ec})=0.16 \mathrm{~mm}$ hos; Water temperature $(T)=27.21^{\circ} \mathrm{C}$; dissolved oxygen $(\mathrm{DO})=7.16 \mathrm{mg} \mathrm{L}^{-1}$ and ammonia-nitrogen $=0.00 \mathrm{mg} \mathrm{L}^{-1}$ according to New et al. (2010). 
Upon initiation of the experiment, juvenile prawns were acclimatized in 6 aquaria for 1 week and were fed with a commercial pellet feed (Havorash, Bushehr, IRI) containing crude protein $(34.93 \pm 0.15)$, crude lipid $(6.48 \pm 0.37)$, crude fiber $(8.26 \pm 0.14)$ and ash $(17.02 \pm 0.29)$ three times daily. The basic ingredients as per the manufacturer of the feed included fish meal, shrimp shell meal, fish oil, squid liver powder, wheat flour, soya meal, lecithin, vitamin and mineral premixes.

Feed trays were used for prawns feeding. The uneaten feed fraction was removed and accounted after $30 \mathrm{~min}$ of feeding. Daily feeding was 5-8\% of total prawns body weight. Feed ration was altered every week based on the estimated feed consumption rate of prawns. The bottom of each aquarium was thoroughly cleaned once a week, at the same time approximately $50-100 \%$ of the water was exchanged. Throughout the experimental rearing period water was well aerated. Photoperiod was maintained at $12 \mathrm{~h}$ Light with artificial fluorescent lighting. Weights of 10 randomly collected prawns from each tank were determined every 2 weeks. Prawn survival was also determined by counting dead prawns in each tank daily. These data were used to estimate survival, wet weight gain (WG), feed conversion ratio (FCR), specific growth rate (SGR) and feed intake (FI) according to keysami et al. (2012):

$$
\begin{aligned}
\text { WG }(\mathrm{g}) & =\text { Final weight }(\mathrm{g})-\text { initial weight }(\mathrm{g}) \\
\mathrm{WG}(\%) & =\mathrm{WG}(\mathrm{g}) / \text { initial weight }(\mathrm{g}) \times 100 \\
\mathrm{FCR} & =\text { Total feed given }(\mathrm{g}) / \mathrm{WG}(\mathrm{g}) \\
\text { SGR }(\%) & =(\ln \mathrm{FPW}-\ln \mathrm{IPW}) / t \times 100 \\
\text { FI }(\mathrm{g}) & =\text { Total feed consumed }(\mathrm{g}) /[(\mathrm{INP}+\mathrm{FNP}) / 2] \\
\text { Survival }(\%) & =(\mathrm{FNP} / \mathrm{INP}) \times 100
\end{aligned}
$$

where: $t=$ time (days); $\ln =$ natural logarithmic; INP $=$ initial number of prawns; $\mathrm{FNP}=$ final number of prawns; IPW = initial prawn body wet weight; FPW = final prawn body wet weight.

\section{Diet preparation}

A $B$. subtilis bacterium isolated from juvenile $M$. rosenbergii gut as described in keysami et al. (2012) were used as probiotics strain. This strain was identified by using biochemical tests according to Bergey et al. (1984), and Biolog Diagnostic System kit and Microstation (Biolog, Inc., CA, USA).

The experimental diets were designated as B. subtilis-treated feed (PF) and control feed (CF). The B. subtilis-treated diet was prepared according to Keysami et al. (2012) by soaking commercially available $M$. rosenbergii pellet feed (Havorash, Bushehr, IRI) with normal saline (NSS; Nacl $8.5 \mathrm{~g} \mathrm{~L}^{-1}$ ) containing the B. subtilis fresh cells. Bacterium was grown for $48-72 \mathrm{~h}$ at $30{ }^{\circ} \mathrm{C}$ in Trypton Soy broth (Difco, CO, USA) and harvested by centrifugation 4,000 g for $15 \mathrm{~min}$. The cells were re-suspended in original volume of saline to $5 \times 10^{13}$ cells $\mathrm{mL}^{-1}$. This suspension was then applied to unsoaked diet to achieve a counted viable dose approximately equivalent to $5 \times 10^{8}$ cells $\mathrm{g}^{-1}$ of feed after absorbing whole bacteria suspension during $1 \mathrm{~h}$. This level of $B$. subtilis $\left(10^{8}\right.$ cells $\left.\mathrm{g}^{-1}\right)$ was chosen based on earlier works of researchers (Meunpol et al. 2003; Keysami et al. 2012). The control diet also was prepared by soaking the same basis pellet feed with normal saline without the B. subtilis fresh cells. The resulting pellets were oven-dried at $32{ }^{\circ} \mathrm{C}$ for $1 \mathrm{~h}$ 
and then dried pellets (200 $\mathrm{g}$ portions of the feed) were packed in sealed plastic bags and used for experiment or stored at $4{ }^{\circ} \mathrm{C}$.

Pathogen challenge test

A pathogenic bacterium, A. hydrophila, obtained from faculty of veterinary, University of Tehran, was used in this challenge experiment by immersion assay after 60 days feeding trial. A. hydrophila had been cultured and maintained using TSB broth and agar. Prawns in all replicates were immersed in a suspension of A. hydrophila at $10^{7}$ cells $\mathrm{mL}^{-1}$ according to Austin et al. (1995). This was followed by a re-immersion of $10^{7}$ cells $\mathrm{mL}^{-1}$ after 7 days (Rengpipat et al. 1998). Water and prawns were collected and checked every 2 days from each tank for microbial examination and prawn survival during the immersing test. The challenge experiment was carried out for a period of 28 days in duplicates and the prawns feeding was continued with experimental diets.

Prawns in each treatment groups were dissected by sterile surgical scissors and examined morphologically and microscopically at day 28 of the challenge test. Prawn survival was also determined for each replicate. A. hydrophila isolated from prawns' gut were purified and identified using biochemical tests, and were compared with the original A. hydrophila cultures. Confirmation of the identity of $A$. hydrophila was done by using Biolog identification kit and software.

\section{Water quality parameters}

Water quality was monitored daily. Temperature and $\mathrm{pH}$ were measured using an YSI (Yellow Spring Inc.), $\mathrm{pH}$ and temperature meter (60-10 FT), respectively. Dissolved oxygen was estimated by an YSI, DO and temperature meter model 57 (USA) and ammonia-nitrogen was estimated by an ammonia meter, HANNA instrument (HI 93715 m; Taiwan), respectively.

\section{Bacteriological study}

Prawns feces (200-300 mg) and one live prawn were collected from each tank, once every 2 weeks for bacterial determination. Prawns were dissected using sterilized surgical scissors and their gut was removed for bacterial enumeration and evaluation. Bacterial enumeration was made using serial dilution in NSS $\left(\mathrm{NaCl} 8.5 \mathrm{~g} \mathrm{~L}^{-1}\right)$ at 10 folds, followed by spread plating on nutrient agar and tryptic soy agar (Difco, CO, USA). After $24 \mathrm{~h}$ of incubation at $32{ }^{\circ} \mathrm{C}$, plate colonies were counted and recorded. Bacterial strains were reexamined using selected morphological and biochemical tests.

\section{Statistical analysis}

Data on growth parameters, prawns survival, water quality, bacteria counts between replicates and treatments were analyzed according to Zar (1984) by using two independent samples $t$ test in SPSS, release16, software (SPSS, Inc., USA). The level of significance was accepted at $(P<0.05)$. 


\section{Results}

Physico-chemical parameters of rearing water

Physico-chemical parameters like water temperature $\left({ }^{\circ} \mathrm{C}\right)$, dissolved oxygen $\left(\mathrm{mg} \mathrm{L}^{-1}\right), \mathrm{pH}$ and ammonia-nitrogen were in ranges of $27.23-29.73{ }^{\circ} \mathrm{C}, 5.5-7.06 \mathrm{mg} \mathrm{L}^{-1}, 7.8-8.07$ and $0.011-0.038 \mathrm{mg} \mathrm{L}^{-1}$, respectively. Values were stable and were within the recommended optimum range for $M$. rosenbergii culture (New et al. 2010). There were no significant differences in water physico-chemical variables between control and treated tanks $(P>0.05)$.

\section{Bacteriological study}

Bacteria from the gut and feces of juvenile prawns after feeding the B. subtilis for 60 days were found to be Bacillus with characteristics similar to the B. subtilis that were used as feed additive.

Bacterial counts in prawns' gut and prawns feces during 60 days of feeding with diet prepared with B. subtilis were presented in Tables 1 and 2. Tables 1 and 2 showed the same pattern of bacterial counts in prawns' gut and feces with different values. After 60 days of culture, gut total bacteria count from each culture tanks was $6.3 \pm 2.6 \times 10^{7}$ cells $\mathrm{mL}^{-1}$, regardless of treatments. Bacillus spp. concentration increased to $2.5 \pm 2.02 \times 10^{6}$ cells $\mathrm{mL}^{-1}$ in treated tanks through the 60 days, but no increment found in the control tanks $\left(2 \pm 0.06 \times 10^{2}\right.$ cells $\left.\mathrm{mL}^{-1}\right)$. Gram-negative bacteria concentrations were $1.1 \pm 0.33 \times 10^{2}$ cells $\mathrm{mL}^{-1}$ in all treated tanks and $4 \pm 1.02 \times 10^{5}$ cells $\mathrm{mL}^{-1}$ in the control tanks through the 60 days.

Gut bacteria of juvenile prawns in control and treated groups after challenge for 28 days were found to be Aeromonas sp. and Bacillus sp., respectively. Bacterial counts in prawns' gut and in rearing tanks water during 28 days of challenge were presented in Figs. 1 and 2. During the challenge test, A. hydrophila concentrations in both rearing water and prawns' gut of the control groups increased to $10^{7}$ cells $\mathrm{mL}^{-1}$, while only $10^{2}$ cells $\mathrm{mL}^{-1}$ of Bacillus spp. were detected. Conversely, with treated groups, the probiont $B$. subtilis was the dominant bacteria $\left(10^{8}-10^{9}\right.$ cells $\left.\mathrm{g}^{-1}\right)$, with lower concentrations of A. hydrophila in

Table 1 Mean log total viable cells bacteria (cells $\mathrm{g}^{-1}$ ), Bacillus and gram-negative bacteria counts in prawns' gut during 10 days of 60 days feeding diets

\begin{tabular}{|c|c|c|c|c|c|c|}
\hline \multirow[t]{2}{*}{ Days } & \multicolumn{2}{|c|}{ Total bacteria count } & \multicolumn{2}{|c|}{ Bacillus count } & \multicolumn{2}{|c|}{ Gram-negative bacteria count } \\
\hline & $\mathrm{CF}$ & PF & $\mathrm{CF}$ & PF & $\mathrm{CF}$ & PF \\
\hline 0 & $2.6^{\mathrm{a}}$ & $2.6^{\mathrm{a}}$ & $1^{\mathrm{a}}$ & $1^{\mathrm{a}}$ & $2.6^{\mathrm{a}}$ & $2.6^{\mathrm{a}}$ \\
\hline 2 & $3.9^{\mathrm{a}}$ & $5.7^{\mathrm{b}}$ & 1 & $2.8^{\mathrm{b}}$ & $3.4^{\mathrm{a}}$ & $2.01^{\mathrm{b}}$ \\
\hline 4 & $4.7^{\mathrm{a}}$ & $5.9^{\mathrm{b}}$ & 1 & $4.6^{\mathrm{b}}$ & $4.3^{\mathrm{a}}$ & $2.02^{\mathrm{b}}$ \\
\hline 6 & $5.3^{\mathrm{a}}$ & $6.3^{\mathrm{b}}$ & 1 & $6.1^{\mathrm{b}}$ & $4.9^{\mathrm{a}}$ & $2.03^{\mathrm{b}}$ \\
\hline 8 & $7.8^{\mathrm{a}}$ & $7.8^{\mathrm{a}}$ & $1^{\mathrm{a}}$ & $7.4^{\mathrm{b}}$ & $5.9^{\mathrm{a}}$ & $2.05^{\mathrm{b}}$ \\
\hline 10 & $2.6^{\mathrm{a}}$ & $2.6^{\mathrm{a}}$ & $1^{\mathrm{a}}$ & $1^{\mathrm{a}}$ & $2.6^{\mathrm{a}}$ & $2.6^{\mathrm{a}}$ \\
\hline
\end{tabular}

These diets were designated as B. subtilis-treated feed (PF) and non-B. subtilis-treated feed (CF), respectively

All values are means of three replicates per treatment

Values containing same superscript in a row for each parameter do not vary significantly $(P>0.05)$ 
Table 2 Mean log total viable cells bacteria (cells $\mathrm{g}^{-1}$ ), Bacillus and gram-negative bacteria counts in prawns feces during 60 days of feeding diets

\begin{tabular}{|c|c|c|c|c|c|c|}
\hline \multirow[t]{2}{*}{ Days } & \multicolumn{2}{|c|}{ Total bacteria count } & \multicolumn{2}{|c|}{ Bacillus count } & \multicolumn{2}{|c|}{ Gram-negative bacteria coun } \\
\hline & $\mathrm{CF}$ & $\mathrm{PF}$ & $\mathrm{CF}$ & $\mathrm{PF}$ & $\mathrm{CF}$ & PF \\
\hline 0 & $2.5^{\mathrm{a}}$ & $2.5^{\mathrm{a}}$ & $1^{\mathrm{a}}$ & $1^{\mathrm{a}}$ & $2.4^{\mathrm{a}}$ & $2.4^{\mathrm{a}}$ \\
\hline 2 & $3.9^{\mathrm{a}}$ & $3.9^{\mathrm{a}}$ & $1^{\mathrm{a}}$ & 2.3 & $2.6^{\mathrm{a}}$ & $2.4^{\mathrm{a}}$ \\
\hline 4 & $4.3^{\mathrm{a}}$ & $4.3^{\mathrm{a}}$ & $1^{\mathrm{a}}$ & $3^{\mathrm{b}}$ & $3.4^{\mathrm{a}}$ & $2.5^{\mathrm{b}}$ \\
\hline 6 & $5.3^{\mathrm{a}}$ & $5.3^{\mathrm{a}}$ & $1^{\mathrm{a}}$ & $3.5^{\mathrm{b}}$ & $3.9^{\mathrm{a}}$ & $2.5^{\mathrm{b}}$ \\
\hline 8 & $5.8^{\mathrm{a}}$ & $5.9^{\mathrm{b}}$ & $1^{\mathrm{a}}$ & $5.2^{\mathrm{b}}$ & $5.3^{\mathrm{a}}$ & $2.6^{\mathrm{b}}$ \\
\hline 10 & $2.5^{\mathrm{a}}$ & $2.5^{\mathrm{a}}$ & $1^{\mathrm{a}}$ & $1^{\mathrm{a}}$ & $2.4^{\mathrm{a}}$ & $2.4^{\mathrm{a}}$ \\
\hline
\end{tabular}

These diets were designated as B. subtilis-treated feed (PF) and non-B. subtilis-treated feed (CF), respectively

All values are means of three replicates per treatment

Values containing same superscript in a row for each parameter do not vary significantly $(P>0.05)$
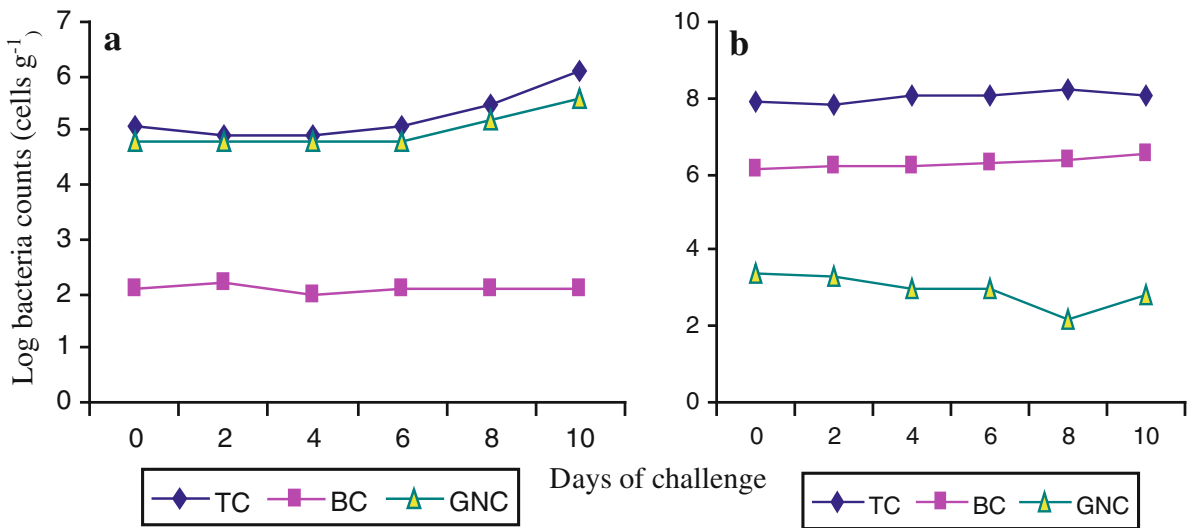

Fig. 1 Log total bacteria (TC), Bacillus (BC) and gram-negative (GNC) bacteria counts (cells $\mathrm{g}^{-1}$ ) in prawns' gut during 28 days of challenge in control (a) and B. subtilis-treated tanks (b)

water $\left(10^{2}\right.$ cells $\left.\mathrm{mL}^{-1}\right)$ and in the gut $\left(2 \times 10^{2}\right.$ cells $\left.\mathrm{g}^{-1}\right)$. The main gram-negative bacteria found in all challenge tanks were identified as A. hydrophila.

Growth parameters

There were significant differences $(P<0.05)$ in weight gain, specific growth rate, feed intake and FCR between the treated and control groups (Table 3 ). Treated groups mean wet weight gain $(1.49 \pm 0.03)$ was significantly $(P<0.05)$ higher than control groups $(0.615 \pm 0.03)$. Prawn survival after 60 days was significantly higher $(P<0.05)$ in the treated groups $(84.23 \pm 1.72)$ than the control groups $(78.22 \pm 2.24 \%$; Table 3$)$.

After 28 days of challenge with A. hydrophila, survival of B. subtilis-treated groups $(88.33 \%)$ was significantly higher $(P<0.05)$ than the control groups $(20.81 \%$; Table 4$)$. Moreover, no external appearance, disease signs and behavioral abnormalities was observed in the treated groups. They looked normal in size, color and appearance, whereas 

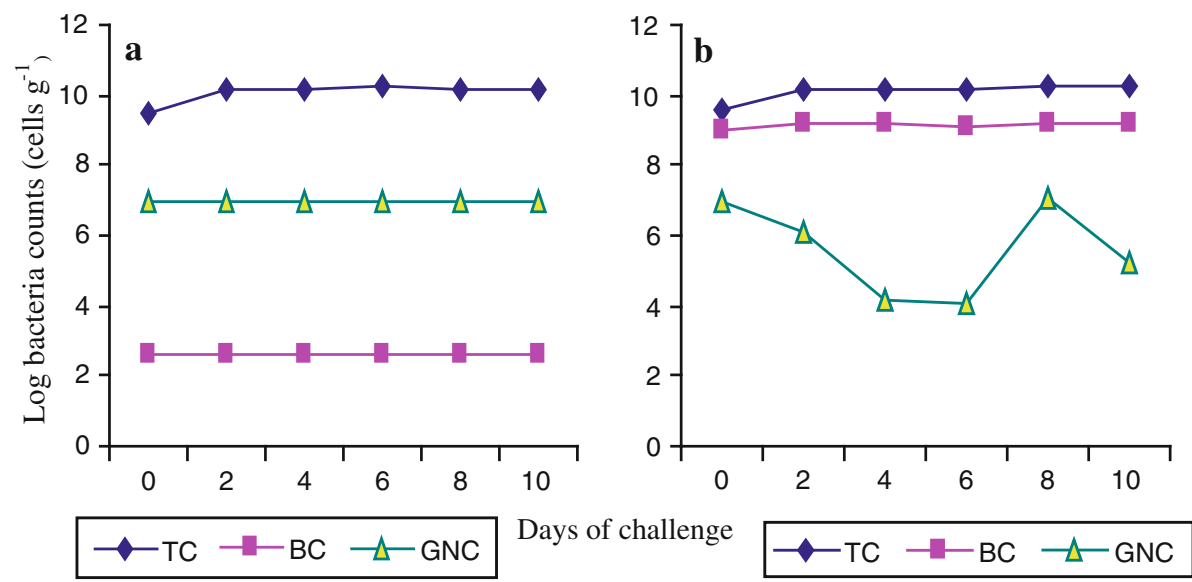

Fig. 2 Log total bacteria (TC), Bacillus (BC) and gram-negative bacteria (GNC) counts (cells $\mathrm{mL}^{-1}$ ) in prawn rearing tank water during 28 days of challenge in control tank (a) and B. subtilis-treated tank (b)

Table 3 Growth-related performance of $M$. rosenbergii during 60 days of feeding diets

\begin{tabular}{lrr}
\hline Growth-related performance & \multicolumn{1}{l}{ CF } & PF \\
\hline Initial mean weight (g) & $0.45 \pm 0.05^{\mathrm{a}}$ & $0.43 \pm 0.01^{\mathrm{a}}$ \\
Final mean weight (g) & $1.06 \pm 0.03^{\mathrm{a}}$ & $1.92 \pm 0.02^{\mathrm{b}}$ \\
Weight gain (g) & $0.62 \pm 0.03^{\mathrm{a}}$ & $1.49 \pm 0.03^{\mathrm{b}}$ \\
Weight gain (\%) & $137.56 \pm 6.34^{\mathrm{a}}$ & $347.88 \pm 17.53^{\mathrm{b}}$ \\
Feed intake (g) & $2.14 \pm 0.02^{\mathrm{a}}$ & $3.12 \pm 0.06^{\mathrm{b}}$ \\
FCR & $3.48 \pm 0.12^{\mathrm{a}}$ & $2.10 \pm 0.03^{\mathrm{b}}$ \\
SGR & $1.44 \pm 0.05^{\mathrm{a}}$ & $2.51 \pm 0.09^{\mathrm{b}}$ \\
Survival (\%) & $78.22 \pm 2.24^{\mathrm{a}}$ & $84.23 \pm 1.72^{\mathrm{b}}$
\end{tabular}

These diets were designated as B. subtilis-treated feed (PF) and non-B. subtilis-treated feed (CF), respectively

All values are means of three replicates per treatment (mean \pm SD)

Values containing same superscript in a row do not vary significantly $(P>0.05)$

infected prawns in the control groups exhibited black spot, necrosis of uropods, lost periopods and pale hepatopancrease.

\section{Discussion}

In this study, it was well demonstrated that the use of B. subtilis as probiotics could efficiently increase the growth and survival of juvenile prawns. These may be attributed to the possibility of higher feed intake and SGR related to treated groups (Keysami et al. 2007). The recent reports on the use of Bacillus spp. (Balcazar et al. 2004; Salinas et al. 2005; Keysami et al. 2012) also demonstrated the beneficial effects of stimulating the growth improvements and gut immune system in the fish and prawn (Abraham et al. 2008). After 60 days of feeding, total bacterial count in water from each culture tank was 
Table 4 Survival of juveniles M. rosenbergii in B. subtilis-treated (PF) and control groups (CF) challenged with A. hydrophila during 28 days

\begin{tabular}{lll}
\hline Time (days) & CF & PF \\
\hline 0 & $100.00 \pm 0.00^{\mathrm{a}}$ & $100.00 \pm 0.00^{\mathrm{a}}$ \\
7 & $63.31 \pm 2.93^{\mathrm{a}}$ & $100.00 \pm 0.00^{\mathrm{b}}$ \\
14 & $49.22 \pm 1.43^{\mathrm{a}}$ & $98.32 \pm 1.43^{\mathrm{b}}$ \\
21 & $30.81 \pm 3.81^{\mathrm{a}}$ & $96.73 \pm 1.72^{\mathrm{b}}$ \\
28 & $20.81 \pm 1.43^{\mathrm{a}}$ & $88.33 \pm 1.53^{\mathrm{b}}$ \\
\hline
\end{tabular}

These diets were designated as B. subtilis-treated feed ( $\mathrm{PF})$ and non-B. subtilis-treated feed (CF), respectively

All values are means of two replicates per treatment (mean $\pm \mathrm{SD}$ )

Values containing same superscript in a column do not vary significantly $(P>0.05)$

$10^{10}$ cells $\mathrm{mL}^{-1}$, regardless of treatment. The same result was reported by Keysami et al. (2012). The B. subtilis concentration increased to $10^{8}-10^{10}$ cells $\mathrm{mL}^{-1}$ in all treated tanks through the first 60 days, but was not found in the control tanks. Bacillus spp. concentrations were $2 \times 10^{2}$ cells $\mathrm{mL}^{-1}$ in the control tanks. Bacillus spp. presence may have been due to non-competitive, saprophytic growth. Nearly similar findings were reported using Bacillus sp. as probiotics in the Litopenaeus vannamei feed (Balcazar et al. 2004; Gullian et al. 2004). It is possible that this phenomenon operates by substitution of opportunist pathogens that reduced growth (Balcazar et al. 2004).

These results indicate that the $B$. subtilis replaced other bacterial species in the culture water. Total bacterial flora, both gram-positive and gram-negative rods, were found in prawns' gut in all treated and control tanks on days 7-8, were in a range of $10^{9}$ $-10^{10}$ cells $\mathrm{g}^{-1}$; similar to results reported by Keysami et al. (2012). The main flora in prawns' gut of the control groups were gram-negative $\left(10^{7}\right.$ cells $\left.\mathrm{g}^{-1}\right)$ and a few Bacillus spp. $\left(10^{2}\right.$ cells $\left.\mathrm{g}^{-1}\right)$, while those in all the treated groups were mostly Bacillus sp. $\left(10^{8}\right.$ $-10^{9}$ cells $\left.\mathrm{g}^{-1}\right)$ and a few gram-negative bacteria $\left(10^{2}\right.$ cells $\left.\mathrm{g}^{-1}\right)$. It appears that, gramnegative bacteria in treated prawns' gut were replaced by $B$. subtilis. This same pattern of bacterial replacement occurred in prawns' feces of treated groups, where gram-negatives were replaced by Bacillus sp. Alternatively, B. subtilis prevented potential pathogens from colonizing the gut by production of antimicrobial compounds or by out competing them for nutrients or mucosal space (Gullian and Rodriguez 2002; Vaseeharan and Ramasamy 2003).

Treatment with $B$. subtilis appeared to enhance growth and survival of $M$. rosenbergii. Gram-negative bacteria in treated prawns' gut were replaced by Bacillus sp. This same pattern of bacterial replacement occurred in rearing tank water and prawns' gut of treated groups in challenge test, where A. hydrophila was replaced by Bacillus sp in rearing tanks water and prawns' gut in B. subtilis-treated tanks. Gram-negative bacteria are the dominant opportunistic bacterial flora in the digestive tracts of prawns. These bacteria are transients and may change rapidly with the intrusion of probiotics bacteria coming from water or feed (Abraham et al. 2008).

Although B. subtilis-treated groups were also immersed in A. hydrophila, they resisted from both external and internal infection of $A$. hydrophila. More importantly, these results are an indirect indication that the $B$. subtilis viably colonize prawns' gut and proliferate in a manner that benefited the host (Renault et al. 2007). The B. subtilis colonization of prawns' gut apparently acted as an interferer or competitor against A. hydrophila infection. 
The $B$. subtilis may produce some antimicrobial substances, or some unknown by-products negatively affected A. hydrophila (Balcazar et al. 2004).

Result of bacterial counts in gut and feces showed that there were significant differences between bacterial counts of prawns in control and treated groups. Gram-negative bacteria counts in prawns of treated groups were significantly lower than control groups. The $B$. subtilis has been shown to produce a wide variety of antibacterial and antifungal compounds in culture media (Chythanya and Karunasagar 2002; Gullian et al. 2004). It produces novel antibiotics such as difficidin and oxydifficidin that have activity against a wide spectrum of aerobic and anaerobic bacteria (Sugita et al. 2002; Gullian et al. 2004). It is expected that gram-negative bacteria would be replaced with probiont strain (Vine et al. 2004). It is assumed that strains showing a dominant colonization of the intestinal mucus of fish and culture water are good candidates to competitively exclude pathogens from the adhesion sites of the gut wall (Wang et al. 2000). However, the use of B. subtilis in prawns feed can reduce juvenile $M$. rosenbergii mortalities during culture. Although the results of this study could be the basis for future studies, our findings should be confirmed in earthen pond trials before they are applied commercially.

Acknowledgments The authors would like to thank the staff of Aquaculture Laboratory and Hatchery unit in Bushehr Persian Gulf Jihad Agriculture Higher Education Center for use of equipments, their financial and technical supports.

\section{References}

Abraham TJ, Babu CHS, Mondal S, Banerjee T (2007) Effects of dietary supplementation of commercial human probiotic and antibiotic on the growth rate and content of intestinal microflora in ornamental fishes. Bangladesh J Fish Res 11(1):57-63

Abraham TJ, Mondal S, Babu CHS (2008) Effects of commercial aquaculture probiotics and fish gut antagonistic bacterial flora on the growth and disease resistance of ornamental fishes Carrasius auratus and Xiphorus helleri. J Fish Aquat Sci 25(1):27-30

Aly SM, Ahmed YA, Ghareeb AA, Mohamed MF (2008) Studies on Bacillus subtilis and Lactobacillus acidophilus as potential probiotics, on the immune response and resistance of Tilapia nilotica (Oreochromis niloticus) to challenge infections. Fish Shellfish Immunol 25:128-136

Anderson IG, Shamsudin MN, Nash G (1989) A preliminary study on the aerobic heterotrophic bacterial flora in giant freshwater prawn, Macrobrachium rosenbergii, hatcheries in Malaysia. Aquaculture 81:213-223

Austin B, Stuckey LF, Robertson PAW, Effendi J, Griffith DRW (1995) A probiotic reducing diseases caused by Aeromonas salmonicida, Vibrio anguillarum and Vibrio ordalii. J Fish Dis 18:93-96

Balcazar JL, de Blas I, Ruiz-Zarzuela I, Vendrell D, Muzquiz JL (2004) Probiotics: a tool for the future of fish and shellfish health management. J Aqucult Trop 19:239-242

Bergey D, Sneath P, John H (1984) Bergey's Manual of systematic Bacteriology, vol 1 section 5. Williams and Wilkins Company, Baltimore

Cai Y, Suyanandana P, Saman P, Benno Y (1999) Classification and characterization of lactic acid bacteria isolated from the intensive of common carp and fresh water prawn. J Gen Appl Microbiol 45:177-184

Chythanya R, Karunasagar I (2002) Inhibition of shrimp pathogenic Vibrios by marine Pseudomonas 1-2 strain. Aquaculture 208:1-10

Colorni A (1985) A study on the bacterial flora of giant prawn, Macrobrachium rosenbergii, larvae fed with Artemia salina nauplii. Aquaculture 49:1-10

FAO (2007) The state of world fisheries and aquaculture 1998. Food and Agriculture Organization FAO, Rome, p 112

FAO/WHO (2001) Report of a joint FAO/WHO expert consultation on evaluation of health and nutritional properties in food including powder milk with live lactic acid bacteria, Cordoba, Argentina

Gullian M, Rodriguez J (2002) Selection of probiotic bacteria and study of their immunostimulatory qualities of probiotic bacteria. Glob Aquacult Adv 5:52-54

Gullian M, Thompson F, Rodriguez J (2004) Selection of probiotic bacteria and study of their immunostimulatory effect in Penaeus vannamei. Aquaculture 233:1-14 
Hoa TTT, Oanh OTH, Phuong NT (2000) Study on diseases in giant fresh water prawn (a review). In: Proceeding of the 2000 annual work shop of JIRCAS, Mecong delta project

Irianto A, Austin B (2002) Probiotics in aquaculture. J Fish Dis 25:633-642

Keysami MA, Saad CR, Daud HM, Sijam K, Alimon AR (2005) A preliminary study to isolation and identification of the aerobic putative bacterial flora in juvenile giant freshwater prawn, Macrobrachium rosenbergii (de Man). In: Kustem 4th annual seminar held at Primula Beach Resort, Kuala Terengganu, Malaysia during 2-3 May 2005. Abstract book, p 78

Keysami MA, Saad CR, Daud HM, Sijam K, Alimon AR (2007) Effect of Bacillus subtilis on growth development and survival of larva Macrobracum rosenbergii (de Man). Aquacult Nutr 13:131-136

Keysami MA, Mohammadpour M, Saad CR (2012) Probiotic activity of Bacillus subtilis in juvenile freshwater prawn, Macrobrachium rosenbergii (de Man) at different methods of administration to the feed. Aquacult Int 20(3):499-511

Meunpol O, Lopinyosiri K, Menasveta P (2003) The effects of ozone and probiotics on the survival of black tiger shrimp (Penaeus monodon). Aquaculture 220:437-448

New MB, Valenti WC, Tidwell JH, D’Abramo LR, Kutty MN (2010) Freshwater prawns biology and farming. Blackwell science, Oxford, p 55

Renault D, Deniel F, Benizri E, Sohier D, Barbier G, Rey P (2007) Characterization of Bacillus and Pseudomonas with suppressive traits isolated from potato hydroponic slow filtration unit. Can J Microbiol 53(6):784-797

Rengpipat S, Phianphak W, Piyatiratitivorakul S, Menasveta P (1998) Effects of a probiotic bacterium on black tiger shrimp Penaeus monodon survival and growth. Aquaculture 167:301-313

Ringo E, Gatesoupe FJ (1998) Lactic acid bacteria in fish: a review. Aquaculture 160:177-203

Rumsey GL, Hughes SG, Kinsella JL (2007) Use of dietary yeast Saccaromyces cerevisae nitrogen by Lake Trout. J World Aquacult Soc 21(3):205-209

Salinas I, Cuesta A, Estteban MA, Meseguer J (2005) Dietary administration of Lactobacillus delbrueckii and Bacillus subtilis, single or combined, on gilthead sea bream cellular innate immune responses. Fish Shellfish Immunol 19:67-77

Scan (2003) Opinion of the scientific committee on animal nutrition on the criteria for assessing the safety of microorganisms resistant to antibiotics of human clinical and veterinary importance. European Commission Health and Consumer Protection Directorate-General

Sotomayure MA, Balcazar JL (2003) Inhibition of shrimp pathogenic Vibrios by mixture of probiotic strain. Rev Aquat 19:9-15

Sugita H, Okamo R, Suzuki Y, Iwai D, Mizukami M, Akiyama N, Matsuura S (2002) Antibacterial abilities of intestinal bacteria from larval and juvenile Japanese flounder against fish pathogens. Fish Sci 68:1004-1011

Vaseeharan B, Ramasamy P (2003) Control of pathogenic Vibrio spp. By Bacillus subtilis BT23, a possible probiotic treatment for black tiger shrimp Penaeus monodon. Lett Appl Microbiol 36:83-87

Venkat HK, Sahu NP, Jain KK (2004) Effect of feeding Lactobacillus-based probiotics on the gut microflora, growth and survival of postlarva of Macrobrachium rosenbergii(de Man). Aquacult Res 35:501-507

Verschuere L, Rombaut G, Huys G, Dhont J, Sorgeloos P, Verstraete W (2000) Probiotic bacteria as biological control agents in aquaculture, review. Microbiol Mol Biol 64:655-671

Vine NG, Leukes WD, Kaiser H, Daya S, Baxter J, Hecht T (2004) Competition for attachment of aquaculture candidate probiotic and pathogenic bacteria on fish intestinal mucus. J Fish Dis 27:319-326

Wang X, Li H, Zhang X, Li Y, Ji W, Xu H (2000) Microbial flora in the digestive tract of adult penaeid shrimp (Penaeus chinensis). J Ocean Univ Qingdao 30:493-498

Zar JH (1984) Bio statistical analysis. Prentice Hall Inc, Englewood Cliffs, p 718 